\title{
WORLD CULTURAL HERITAGE MONUMENTS IN KOSOVO AND METOHIJA - PROBLEMS AND PERSPECTIVES OF PROTECTION
}

Оригиналан научни рад, рад примљен: октобар 2021, рад прихваћен: новембар 2021

Марко Николић*, Марта Вукотић Лазар**, Мирјана Ротер Благојевић***

\section{АПСТРАKТ}

Године 2006. Комитет за светску културну и природну баштину Унеска (UNESCO) уписао је четири српске средњовековне светиње са простора Косова и Метохије - Цркву Богородице Љевишке у Призрену и манастире Пећку патријаршију, Дечане и Грачаницу, на Листу светске баштине у опасности, услед потешкоћа у њиховом очувању и управљању, као и због штете коју су претрпели током етничких сукоба. У складу са Резолуцијом Уједињених нација 1244, они се тренутно налазе под контролом Мисије Уједињених нација на Косову и Метохији. Међутим, осим ових споменика, културни и демографски идентитет Срба на Косову и Метохији илуструје и преко 1500 утврђених културних добара (манастири, цркве, гробља итд.) која сведоче 0 вековном присуству српског народа и православне вере на овом простору и њихове материјалне и духовне културе, као дела укупне европске културне баштине настале у преплитању утицаја источне и западне хришћанске религије и културе.

Укључивање наведена четири културна добра од изузетног значаја за (рбију у међународни систем заштите и праћења (мониторинга) утицало је да се на међународном нивоу покрену разматрања целовитог и дугорочног сагледавања културног наслеђе на Косову и Метохији као кључног елемента у успостављању бољих културних и свеукупних односа између српског и албанског становништва.

У раду се разматрају проблеми и могућности побољшања заштите и презентације светске културне и природне баштине на Косову и Метохији, као и проширење ове Листе, кр0з интеграцију међународне, националне и локалне заштите и разумевање овог подручја као специфичног културног пејзажа. Кроз презентацију њихових вредности као свеобухватног културног пејзажа, који обједињује

\footnotetext{
* др Марко Николић, доцент, Универзизтет у Београду - Архитектонски факултет, marko@arh.bg.ac.rs

** др Марта Вукотић Лазар, ванредни професор, Универзитет у Приштини са привременим седиштем у Косовској Митровици - Филозофски факултет, marta.vukotic@gmail.com

*** др Мирјана Ротер Благојевић, редовни професор, Универзитет у Београду Архитектонски факултет, roterm@arh.bg.ac.rs
}

природне материјалне и нематеријалне аспекте наслеђа, као и организацију културних, образовних и других активности, било би подстицано поштовање различитости, интегритета и идентитета онога другог, што је низбежан услов у процесу европске интеграције и повезивања тренутно супротстављених етничких група.

Кључне речи: светска културна и природна баштина, Косово и Метохија, манастири и цркве, заштита, културни пејзаж

\section{ABSTRACT}

In 2006, the UNESCO World Cultural and Natural Heritage Committee inscribed four Serbian medieval shrines from Kosovo and Metohija on the World Heritage List, in danger due to difficulties in their preservation and management, as well as the damage they suffered during ethnic conflicts, namely: the Church of Bogorodica Ljeviška in Prizren and the PećPatriarchate, Dečani and Gračanica monasteries. In accordance with United Nations Resolution 1244, they are currently under the control of the United Nations Mission in Kosovo and Metohija. However, in addition to these monuments, the cultural and demographic identity of Serbs in Kosovo and Metohija is illustrated by over 1,500 established cultural assets (monasteries, churches, cemeteries, etc.) that testify to the centuries-old presence of the Serbian people and Orthodox faith in this area and their material and spiritual culture, as works of the overall European cultural heritage created in the intertwining of the influences of Eastern and Western Christianity and culture.

The inclusion of these four cultural assets of great importance for Serbia in the international system of protection and monitoring has led to initiating the consideration of a comprehensive and long-term view of cultural heritage in Kosovo and Metohija at the international level as a key element in establishing better cultural and overall relations between Serbs and the Albanian population.

The paper discusses the problems and possibilities of improving the protection and presentation of World Cultural and Natural Heritage in Kosovo and Metohija, as well as the expansion of the list, through the integration of international, national and 
local protection, and understanding of this area as a specific cultural landscape. Presenting the value of the heritage as a comprehensive cultural landscape which combines natural tangible and intangible aspects, as well as the organization of cultural, educational and other activities, would encourage respect for the diversity, integrity and identity of others, which is an unavoidable condition in the process of European integration currently opposed by ethnic groups.

Keywords: World cultural and natural heritage, Kosovo and Metohija, monasteries and churches, protection, cultural landscape

УВОД

Упркосчињеници дауништавање српске духовнеи културне баштине на територији Косова и Метохије траје више од шест векова, густина српских средњовековних споменика, претежно црквених, и даље је изузетно велика, а посебно у односу на тако малу територију. На овом простору је сачувано преко 1500 светиња (манастира, цркава, старих српских гробаља, тврђава, двораца итд.), које сведоче 0 вековном присуству српског народа и православне вере на овом простору.' Ове две средишње области Старе Србије нераскидиви су део српског државног, културног и духовног идентитета, од средњег века до данас.

Према важећем Закону о културним добрима из 1994. године (Službeni glasnik RS, 1994), поједини представници материјалне културе су уписани као културна добра Републике Србије, споменици културе, просторне културноисторијске целине, археолошка налазишта и знаменита места (RZZSK RS, 2016; Milić i Рejić, 1998). Поред уписа у национални регистар заштите, споменици културе од

1 Картограф Љубиша Гвојић, на својој карти Српски белези на Косову и Метохији, приказао је 534 стара српска гробља, 96 тврђава и старих градова и 14 српских средњовековних двораца, затим 1181 цркву, 113 манастира, 48 испосница, 8 спомен-капела и спомен костурница. На крају списка на Гвојићевој карти наведено је да списак није коначан. 0 томе видети у: Pavlović, M., P. Marković (2006) Kosovo i Metohija: prošlost, pamćenje, stvarnost, Novi Sad, Preporod MM, str. 293.




изузетног значаја - Црква Богородице Љевишке уризрену и манастири Пећка патријаршија, Дечани и Грачаница уписани су на Листу светске баштине у опасности 2006. године као средњовековни манастири на Косову (Medieval Monuments in Kosovo, UNESCO List of World Heritage in Danger, 2016). Ово је био важан корак ка интернационализацији и унапређењу њихове заштите, будући да се почетком осамдесетих година двадесетог века процес распада бивше Југославије, праћен лошом економском ситуацијом и оружаним сукобима, крајње негативно одразио и на укупну заштиту културно-историјског наслеђа у Србији, а посебно на Косову и Метохији. Мада је више од 300 споменика српске културе било под законском заштитом, од тога је половина оштећена или уништена, а само је у мартовском погрому 2004. године у једном дану тешко оштећено више од 36 цркава (Pavlović, Marković, 2006:293). (С. 1)

Политичке и друштвене промене у Републици Србији након 2000. године иницирале су процесе демократизације и успостављања чвршћих веза са Европом. Након окончања оружаних сукоба, према Резолуцији 1244 UNSC из 1999. године, Косово и Метохија су били под привременом међународном управом. То је био разлог да Министарство културе Републике Србије није директно разматрало културно наслеђе Косова и Метохије у Извештају о процени Европске комисије повезаном са заједничким програмом Савета Европе: Интегрисани план пројекта рехабилитације, Преглед архитектонског и археолошког наслеђа (The Assessment Report for European Commission connected with Council of Europe Joint Programme: Integrated Rehabilitation Project Plan, Survey of the Architectural and Archaeological Heritage /IRPP/SAAH), од 13. новембра 2008. године (ПРИЛ, стр. 8). Упркос позитивним напорима у домену заштите и очувања културног наслеђа у (рбији је и даље транзициона фаза праћена бројним проблемима који су последица сталних политичких сукоба у региону и који представљају константан ризик на пољу очувања наслеђа, посебно на простору Косова и Метохије (ПРИЛ, 9-10). Један од кључних проблема представља неусклађеност садашњег Закона о културним добрима (1994) са новим међународним препорукама, те више од две деценије постоје напори за ревизијом овог акта и његовим усклађивањем са новим концептима заштите уведеним кроз међународне препоруке (Roter-Blagojević et al. 2016:125-128). Од укупно ратификованих 14 међународних докумената, седам од стране Савета Европе и седам од стране Унеска, након 2000. године су потписане веома значајне конвенције чији би елементи требало да се уграде у нови закон - Конвенција о очувању нематеријалног културног наслеђа (Unesko, Pariz, 2003); Конвенција о заштити и унапређењу разноликости културних израза (Unesko, Pariz, 2005) и Оквирна конвенција Савета Европе о вредности култуног наслеђа за друштво (Savet Evrope, Faro, 2005) (Ministarstvo kulture RS, 2016).

Иакосупотписанеконвенције обавезујућизаконскипрописи, њихова примена у пракси је недовољна, што јасно указује на то да у контексту разматрања политичких и економских проблема заштита културног и природног наслеђа захтева оснаживање веза са међународним организацијама, њихову финансијску подршку, као и подршку у домену стручних размена и сарадњи професионалаца из целог света, посебно на простору Косова и Метохије. Поред тога, нове међународне препоруке у области културног наслеђа, кроз концепт одрживог развоја, који је незаобилазни део сваког деловања у данашњем друштву, промовишу да културно одрживи развојмораузети обзир интелектуалне, моралне и естетске стандарде заједнице, а кроз концепт културног пејзажа захтевају холистички приступ који повезује природно, материјално и нематеријално наслеђе у целину. Оне пружају могућности да се на свеобухватнији начин заштите манастири и цркве на Косову и Метохији и да се они представе свету као јединствене и непоновљиве културне вредности које обједињују природне, друштвене, културне и уметничке аспекте простора на ком су настале, али, и да се, што је још важније, повежу локалитети светске културне и природне баштине са процесом превазилажења етничких тензија, несметаног локалног развоја и отварања нових могућности на путу остварења суживота српске и албанске заједнице на овом простору.

У складу са наведеним, главни циљ овог рада је да укаже на нове могућности приступа и методологије рада у области заштите и презентације културног наслеђа, као дела остваривања хармоничног развоја друштва у складу са интегративном заштитом културног наслеђа региона, засноване на Европској конвенцији о пејзажу, усвојеној на Савету Европе у Фиренци (European Lanscape Convention, Council of Europe, 2000), која није ратификована у (рбији, и на Фарској конвенцији Савета Eвpone (Faro Convention, Council of Europe, 2005).

\section{СПОМЕНИЦИ КУЛТУРЕ СВЕТСКЕ БАШТИНЕ НА ПРОСТОРУ КОСОВА И МЕТОХИЈЕ}

Комитет за светску баштину уписао је манастир Дечане на Листу угрожене светске баштине 2004. године, а потом је одлучио да прошири Листу уписом још три угрожене целине са манастирима Пећка патријаршија и Грачаница и Црквом Богородице Љевишке у Призрену, номинованим од стране Србије под називом Средњовековни српски споменици на Косову и Метохији (Serbian Medieval Monuments of Kosovo and Metohija). На наредним заседањима Унесковог комитета три активна српска манастира и једна црква на Косову и Метохији добили су заједнички назив (редњовековни споменици на Косову (Medieval Monuments in Kosovo) и под тим називом су уписани и на Листу светске баштине у опасности (2006) на којој се и данас налазе (Kesić Ristić et. al., 2010). Препознавши их као средњовековне споменике на Косову из XIII и XIV века у опасности, Комитет је одлучио да их стави на ову Листу због великих и непремостивих потешкоћа у домену њиховог очувања и управљања, проблема који проистичу из константне политичке нестабилности на овим просторима, која се прелива на 

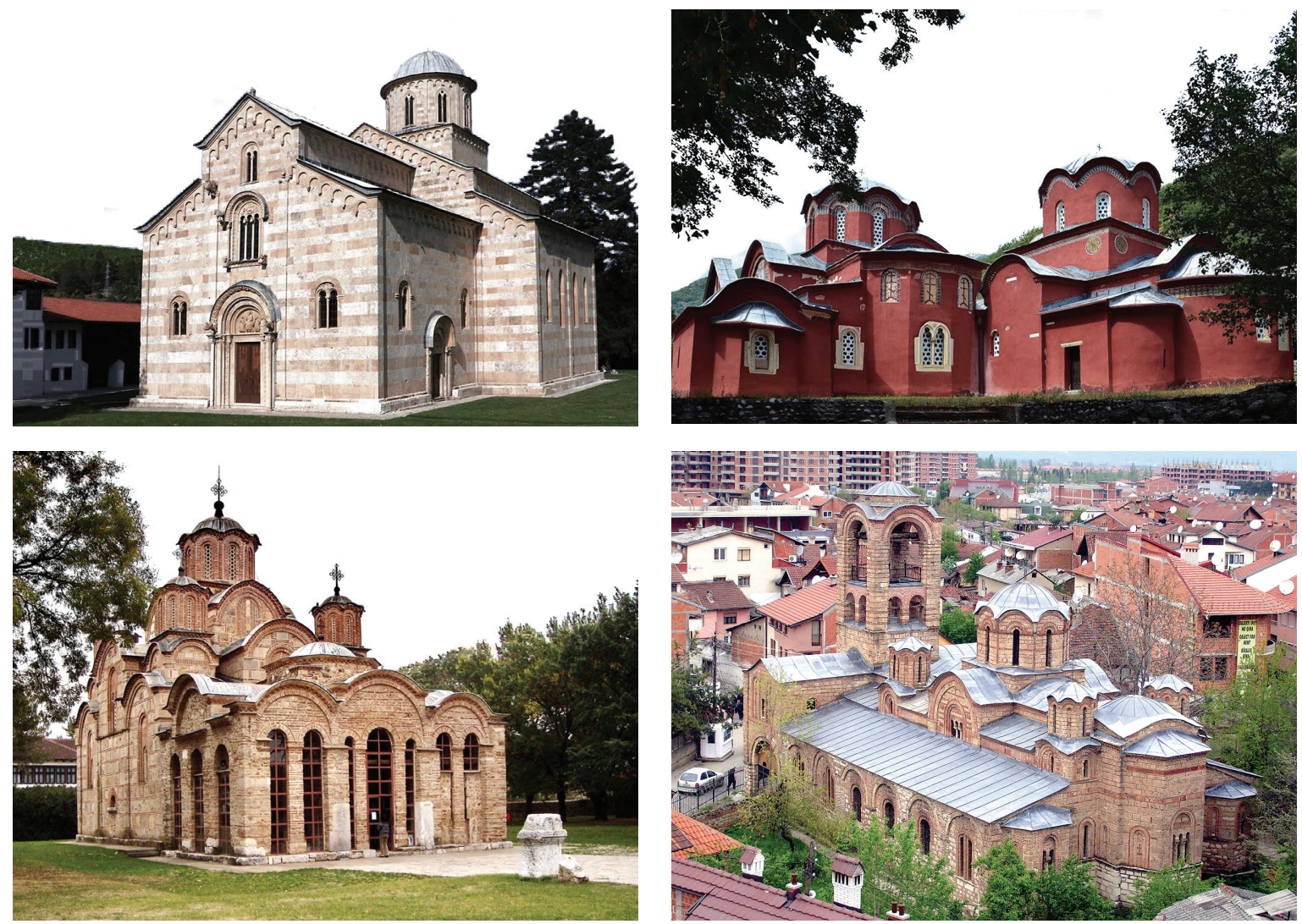

Слика 2. Споменици културе светске баштине на Косову и Метохији у опасности - Дечани, Пећка патријаршија, Грачаница и Богородица Љевишка Fig. 2. World Heritage Cultural Monuments in Kosovo and Metohija in Danger - Dečani, Pećka Patriarchate, Gračanica and Bogorodica Ljeviška

читав регион, и која не јењава до данашњих дана (Krstić, 2004:27-34). У том смислу, Комитет захтева од Србије да, као држава потписница, сарађује са програмима Унеска, са Мисијом Уједињених нација на Косову (УНМИК) и са Привременим институцијама самоуправе на Косову, а у циљу заједничке бриге о споменицима светске културне и природне баштине. То такође укључује мониторинг Унеска који се спроводи у сарадњи са земљом у којој се налази угрожени локалитет и уз финансијску подршку за заштиту тог локалитета до постепеног смањења степена угрожености, односно до потпуне заштите и безбедности споменика културе (Nikolić et al., 2019:351-360).

Наведени споменици представљају најзначајније и типичне споменике рашке и византијске стилске групе у оквиру српске средњовековне уметности, чији је значај у типологији просторног распореда и конструктивног склопа, као и њиховог обликовања под утицајима западне романичке и источне византијске архитектуре. Изузев архитектонских вредности, њихова уметничка вредност се огледа и у домену фреско-сликарства из XIII и XIV века.

\section{Манастир Дечани}

Подигнут је на излазу из клисуре реке Дечанске Бистрице, у подножју планине Проклетије, недалеко од села Дечани на Косову и Метохији. Као споменик културе, 1997. године уписан је у Централни регистар као непокретно културно добро од изузетног значаја. Споменик је у надлежности Републичког завода за заштиту споменика културе
Републике Србије у Београду и Канцеларије за очување културног наслеђа на Косову и Метохији у Београду. Манастир је као своју задужбину и маузолеј основао краљ Стефан Дечански, а након његове смрти радове на манастиру наставио је његов син Душан. Изградио га је фра Вита Которанин између 1327. и 1335. године, под утицајем романичке архитектуре у обликовању цркве. Фреско-сликарство је сачувано готово у целини и састоји се од 1000 појединачних фигура и сцена класификованих у више од 20 периода, те отуда представља највећи сачувани извор података византијске иконографије. Конзерваторски радови, започети још тридесетих година XX века, спроводе се на целом комплексу и трају до данашњих дана, и то првенствено у домену чишћења живописа и санирања угрожене камене пластике и фасада (RZZSK RS, 2019; RZZSK, 1999:70-71).

\section{Манастир Пећка патријаршија}

Налази се недалеко од Пећи, на самом улазу у Руговску клисуру на Косову и Метохији. Као споменик културе, 1997. године уписан је у Централни регистар као непокретно културно добро од изузетног значаја. Споменик је у надлежности Републичког завода за заштиту споменика културе Републике Србије и Канцеларије за очување културног наслеђа на Косову и Метохији. Црквени комплекс је одувек био духовно седиште, као и маузолеј српских архиепископа и патријараха. Храм светих апостола подигао је у трећој деценији XIII века архиепископ Арсенија I, чијом 
заслугом је црква и осликана око 1260. године. Архиепископ Никодим је у периоду између 1321-1324. године подигао Храм Светог Димитрија дуж северне стране Цркве светих апостола, докје архиепископ Данило II (1324-1337) саградио Цркву Богородице Одигитрије и Цркву Светог Николе са јужне стране стране матичне Цркве светих апостола. Испред западних фасада цркава Светог Димитрија, Светих апостола и Св. Богородице Одигитрије, Данило II је саградио монументални нартекс у облику импозантног отвореног улаза. На зидовима Пећке патријаршије може се видети целокупна историја стилова средњовековног зидног сликарства. Манастир је у процесу константне конзервације (RZZSK RS, 2019; RZZSK, 1999:44-45).

\section{Манастир Грачаница}

Налази се у Грачаници, у близини Приштине на Косову и Метохији. Као споменик културе, 1997. године уписан је у Централни регистар као непокретно културно добро од изузетног значаја. Споменик је у надлежности Републичког завода за заштиту споменика културе Републике Србије и Канцеларије за очување културног наслеђа на Косову и Метохији. Црква у манастиру Грачаница посвећена је Успењу Пресвете Богородице, задужбина је краља Милутина из друге деценији XIV века и подигнута је на старијим темељима, што одликује већи број његових задужбина. Изграђена је у форми петокуполне грађевине са основом у облику уписаног крста. Средином XIV века уз цркву је дозидана спољња припрата. Радови на конзервацији архитектуре и живописа одвијају се перманентно (RZZSK RS, 2019; RZZSK, 1999:58-61).

\section{Црква Богородице Љевишке}

Налази се у граду Призрену на Косову и Метохији и једина је сачувана средњовековна градска епископска црква. Као споменик културе, 1997. године уписана је у Централни регистар као непокретно културно добро од изузетног значаја. Споменик је у надлежности Републичког завода за заштиту споменика културе Републике Србије и Канцеларије за очување културног наслеђа на Косову и Метохији. Црква у Призрену посвећена је Пресветој Богородици и подигао ју је краљ Милутин 1306/1307. године на остацима базилике из XIII века, која је лежала на темељима цркве из средњовизантијског периода (IX-XI век). Протомајстор Никола је изградио, архитектонски гледано, изузетно здање, петокуполну цркву уписаног крста, опасану бочним опходним бродом и припратом са отвореним тремом (данас зазиданих пролаза) и са кулом на западној страни. Здање је у време турске владавине претворено у џамију, када су фреске обијене длетом и прекривене дебелим слојем малтера. Живопис изузетне вредности, дело протомајстора Астрапе из Солуна са сарадницима (око 1310-1313), и поред тога што је умногоме оштећен, спада у домен најуспелијих фреско-целина из периода владавине византијске династије Палеолога. Педесетих година XX века урађени су конзерваторско-рестаураторски радови на архитектури, а сликарство је откривено испод слојева креча у периоду 1950-1952. године, а затим је чишћено и ретуширано у више наврата у периоду 1969-1979. године. Црква је гађана из ватреног оружја, а потом и спаљена, у марту 2004. године, када су оштећени портрети Немањића у нартексу и кули, а у мањој мери и слике у наосу (RZZSK RS, 2019; RZZSK, 1999:97-98). (Сл. 2)

\section{ИСТОРИЈА СТРАДАЮА И УПИСИВАҢА СРПСКИХ СПОМЕНИКА КУЛТУРЕ НА ЛИСТУ СВЕТСКЕ БАШТИНЕ}

Разноликост међу верским и етничким групама трансформисана у растућем и отвореном непријатељству, резултирала је етничким чишћењем српског народа са територије Косова и Метохије, праћеним непрекидним насртајима на српско наслеђе, као симбол вере и етничке припадности овог аутохтоног становништва. Страдање Срба и њихово протеривање са Косова и Метохије датирају још из средњег века, док су српски споменици на том подручју изложени опасности још од краја XVII века. У XX веку, како током ратова, тако и у кратким периодима мира, девастација српског наслеђа на Косову и Метохији последица је, пре свега, намерног уништавања, а крајем века дошло је до све бруталнијег и масовнијег уништавања овог подручја. Будући да се ради о наслеђу других, нова албанска политичка заједница приступа српском наслеђу као неприхватљивом, што је резултирало тиме да је, са једне стране његов опстанак на простору Косова и Метохије угрожен до крајњих граница, а са друге стране оно је изложено константним нападима у виду прекрајања чињеница и нових тумачења, у циљу политичке употребе прошлости и у сврху креирања нових идентитета на овим просторима.

Прва фаза уништавања српског наслеђа у другој половини XX века, која је трајала од 1945. до 1966. године, била је обележена сталним нападима на црквену имовину, подметањем пожара и девастацијом православних гробова на гробљима, а што су локалне власти константно толерисале. Истовремено, то је био и период доношења низа закона у духу новог друштвеног и државног поретка, помоћу којих су власти неправично заплениле имовину српских манастира. Нова фаза - децентрализација државе - обележена је изостављањем имена Метохија из пуног назива српске Аутономне покрајине Косово и Метохија, од стране комунистичког режима СФР и косовских Албанаца 1968. године. Брисање дела имена Метохија, појма изузетно српске и православне конотације, симболично је најавило правце националне политике албанских комуниста на Косову и Метохији, који ће произвести висок степен етичке хомогенизације и националне дискриминације против српског, и мањим делом, и другог неалбанског становништва (Bataković, 1998:183).

Ова пракса била је у функцији елиминисања и порицања српског националног и верског карактера ове области, са циљем да доведе до њене потпуне сецесије од Србије. 
Уништавање православних гробаља и спаљивање цркава, као и генерално време страха и несигурности од косовских Албанаца, наставило се и у периоду од 1969. до 1981. године. Дискриминација на националној основи свакодневно се исказивала на улици, у јавном простору (писање непријатељских и увредљивих парола по градовима, (елима, црквама, гробљима итд.), где се захтевало и да се прича само албанским језиком, да би се Србима показало да живе не само у непријатељској средини, већ и у страној држави.

Масовни и јавни захтеви албанске мањине за успостављањем Републике Косово изнесени су у пролеће 1981. године, непуну годину после смрти Јосипа Броза Тита. Пет дана након насилних демонстрација Албанаца у Приштини који су захтевали независну Републику Косово, у ноћи 16. марта 1981. године спаљен је древни двоетажни конак Пећке патријаршије, и тако је паљењем овог симбола српског православља још снажније најављен сецесионистички покрет, а потом су се напади ширили даље, на цркве и манастире Косова и Метохије: Грачаницу, Девич, Манастир (в. Марка код Призрена, Самодрежу итд. Република Албанија у време Енвера Хоџе (1945-1985) спроводила је систематску и опсежну пропаганду против Југославије и Србије, која се одвијала у више етапа континуалне политике, која је мењала тактике, али не и стратегију, и која је свој епилог добила у првом великом важном скупу солидарности с косовским Албанцима одржаном у Тирани крајем јануара 1992. године, одмах после признавања независности Хрватске и Словеније. Српско-албански сукоб на Косову и Метохији и етничко ривалство Срба и Албанаца, у геополитичком контексту и из историјске перспективе, стари су неколико векова и имају препознатљиви континуитет (Bataković, 1998:198, 216, 217).
Крајем XX века дошло је до таласа све разорнијих напада на српско наслеђе од стране албанских екстремиста. Ови напади на територији Косова и Метохије су били праћени албанским терором, скрнављењем и уништавањем цркава, манастира и гробаља, када су оштећени и бројни споменици, међу којима је и манастир Грачаница. Такође, најстарија српска кућа - кућа брвнара Даниловића у селу Лоћане надомак Дечана, спаљена је тада до темеља.

Крај XX и почетак XXI века обележио је наставак интензивне и драматичне патње и страдања Срба. У овом периоду уочавају се следеће промене у динамици и врсти претњи: први талас насиља и разарања је трајао од 1999. до 2001. године, а након насиља уследио је релативно миран период са повременим инцидентима, у трајању од 2001. до 2004. године, који је, како се касније могло сагледати, само најавио мартовски погром из 2004. године, током којег је у року од четири дана уништен и опљачкан велики број цркава, кућа и гробаља (Pavlović, Marković, 2006:377-395; Reljić, 2020: 21). Након овог погрома уследиће релативно миран период од 2004. године до данас, којег ће обележити, са једне стране почетак обнављања српске баштине и светиња, али и све интензивнија и континуална пропагандна активност од стране косовских Албанаца и њихових институција, у циљу прикривања и прекрајања утемељених чињеница 0 идентитету српске баштине и културе. Један од многобројних средњовековних споменика који је намерно уништен и подвргнут оваквој врсти мењања чињеница је Црква Богородице Љевишке у Призрену, која се узима као парадигма односа савременог албанског друштва на Косову и Метохији према српској средњовековној баштини. Ипак, оно што се годинама дешавало, без обзира на динамику и разорност тих акција, јесте систематско, смишљено и упорно спровођење уништавања баштине као материјалног сведочанства и поништавање и рушење нематеријалне културне баштине и сећања (Pavlović, Marković, 2006: 422-435). (Сл. 3)

Слика 3. Уништавање цркава на простору Косова и Метохије / Fig. 3. Destruction of churches in Kosovo and Metohija








Слика 4. Црква Богородице Љевишке у опасности / Fig. 4. Church of Bogorodica Ljeviška in danger

Мада је од 1999. године Аутономна покрајина Косово и Метохија под протекторатом УНу оквиру Савезне Републике Југославије (СР), у складу са Војно-техничким споразумом или Кумановским споразумом и Резолуцијом 1244 Савета безбедности УН, долазак међународних снага није окончао патњу Срба и разарање њихове баштине. Значајно је да су међународне мисије (Унеско, Савет Европе) потврдиле уништавање српског историјског, културног и духовног наслеђа, што ће резултирати уписивањем три манастира - Дечани, Грачаница и Пећка патријаршија, и једне цркве - Богородице Љевишке у Призрену на Унескову Листу светске баштине. Уписивање српских споменика на Косову и Метохији на ову листу представљало је веома сложен процес, који је званично отпочео 1985. године, када је (ФРЈ поднела прелиминарни списак са 18 потенцијалних културних и природних добара, међу којима су били и средњовековни манастири на Косову и Метохији Грачаница и Дечани. Догађаји који супотом закомпликовали овај процес, а понекад га и обесмишљавали, јесу следећи: држава која је именовала културна добра двапут се променила док се име подносиоца захтева променило једном. Први подносилац је била (ФРЈ (до 1992), потом Савезна Република Југославија (1992-2003), онда Србија и Црна Гора (2003-2006) и коначно Република Србија (од 2006). Процес именовања је поново покренут 2000. године, након повратка Србије у Уједињене нације и Унеско. На 28. седници Комитета светске баштине 2004. године, манастир Дечани је уврштен на Листу, након чега је уследио рад на процесу проширења Листе манастирима Грачаница и Пећка патријаршија, као и црквом Богородице Љевишке у Призрену, под називом Средњовековни српски споменици на Kосову u Memoxuju (Serbian Medieval Monuments of Kosovo and Metohija).
На 30. седници Комитета 2006. године, две године након уписивања манастира Дечани, тражено проширење је прихваћено, али уз одрећене измене, укључујући делимичну промену назива споменика у Средњовековни споменици на Косову (Medieval Monuments in Kosovo), а уписани споменици су укључени и на Листу светске културне баштине у опасности. 3бог све чешћих етнички мотивисаних напада на српску културну баштину, који су се несметано настављали, било је неопходно да се успоставе заштићене зоне око српских светиња, како би се осигурала њихова безбедност. (Сл. 4) Српски стручњаци су припремили техничку документацију за потребе преговора у Бечу 2006. године, у вези са заштићеном зоном на 39 комплекса где се налазе 24 манастира. Оно што је уследило био је Анекс V Ахтисаријевог плана за верско наслеђе, на чије је професионалне недостатке, у смислу одређивања зоне заштите и управљачке зоне, српски преговарачки тим одмах указао 2007. године на новим преговорима у Бечу. Међународна заједница је ипак одлучила да подржи Ахтисаријев план и такозвану пратећу законску регулативу о посебним зонама заштите на датим локацијама, које су нестручно и некомпетентно начињене од стране такозваних Привремених институција самоуправе Косова и Метохије. Поред тога, Ахтисаријев план је подржао модел обнове српских споменика у складу са Меморандумом који је у два наврата потписала Српска православна црква (СПЦ) са такозваним Привременим институцијама самоуправе Косова, у присуству УНМИК-а са Саветом Европе, задуженим за спровођење обнове. Српско културно наслеђе на Косову и Метохији, нажалост, још увек није стављено под праву и ефикасну заштиту Унеска, зато што је још увек у тешкој 
ситуацији, изложено разним изазовима, који су се додатно закомпликовали општим аргументима ИКОМОС-а у вези са критеријумима за упис на Листу, према којима се уписани средњовековни манастири и цркве на Косову и Метохији третирају више као део универзалног средњовековног романичког и византијског градитељства и уметности, него као плод аутохтоне српске баштине. Све ово је утирало пут ка другачијем и искривљеном тумачењу српског средњовековног наслеђа, које не одговара ни историјским чињеницама, нити савременим научним стандардима. у случају чланства самопроглашене државе Косово у Унеску (Захтев је поднела Албанија 2015. године), сви средњовековни споменици на Косову и Метохији, које је Србија са великим напорима и мноштвом потешкоћа уврстила на Листу светске културне баштине у опасности као своје највредније наслеђе, биће на Листи светске баштине Косова и Метохије, односно припашће онима који у сваком смислу негирају њихову вредност и значај, упркос чињеници да су потврђени од стране Унесковог Комитета за светску баштину (Marković, 2016).

\section{НОВИ ПРИСТУПИ И СТРАТЕГИЈЕ ЗА ЗАШТИТУ,} ПРЕЗЕНТАЦИЈУ И УПРАВЉАҢЕ СВЕТСКОМ БАШТИНОМ НА КОСОВУ И МЕТОХИЈИ КАО КУЛТУРНИМ ПЕЈЗАЖОМ

Иако су неки од најзначајнијих средњовековних споменика културе на Косову и Метохији уписани на Листу светске баштине у опасности, бројне су цркве и манастири од изузетног историјског значаја и културне вредности за Србију који су перманентно изложени опасности, али их још увек нема на Листи. У првом реду то су манастир Бањска (Сл. 5), недалеко од града Косовска Митровица, који је на месту старијег храма између 1312-1316. године подигао краљ Милутин као своју задужбину и маузолеј, и Манастир Св. Арханђела (у највећој мери уобличен у периоду 1343-1352. године), у клисури реке Бистрице, 3 км од града Призрена, који је уједно и маузолеј најмоћнијег српског средњовековног владара, а потом цара (1346), Душана. (Сл. 6) Српски средњовековни утврђени градови Каљаја, Ново Брдо, Звечан, Неродимље и Петрич су такође у веома лошем стању, а изузетан пример средњовековног града који би морао бити уписан у целости на Листу светске баштине је Призрен, који обухвата не само цркву Св. Богородице Љевишке, манастир (в. Арханђела, тврђаву Каљаја и средњовековну епископалну палату Подкаљај, већ и значајно отоманско наслеђе, као што су Синан-пашина џамија, Хамам, односно 15 културних знаменитости од изузетног значаја за Републику Србију (RZZSK RS, 2016; RZZSK, 1999:33-34; 97-114).

Све наведено намеће другачији приступ заштити на Косову и Метохији и испитује могућности класификације ширег подручја око најзначајнијих средњовековних манастира или средњовековних градова који садрже српско и отоманско наслеђе из средњовековног периода, као и периода након средњег века, у оквиру националног и интернационалног система заштите, као културног пејзажа, непоновљиве органске целине, визуелне појаве околине која се пружа пред нашим очима и која се у односу са свим другим целинама одликује специфичношћу и хомогеношћу. Управо природне и географске карактеристике простора, у садејству са деловањем људи на природно окружење и утицајем њихове духовне културе на грађену средину дају специфичан и непоновљиви печат сваком културном пејзажу.

Слика 5. Манастир Бањска / Fig. 5. Banjska Monastery

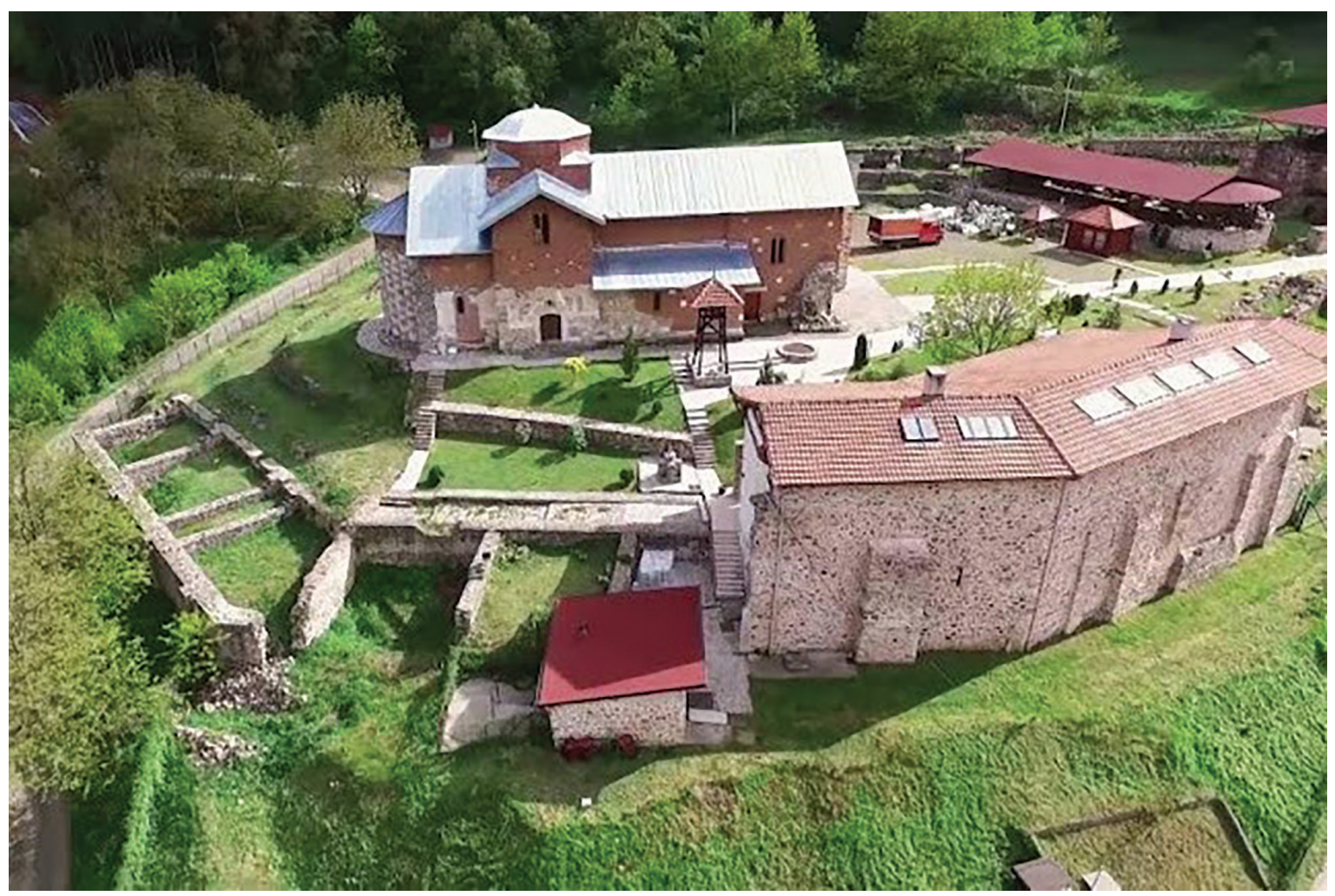




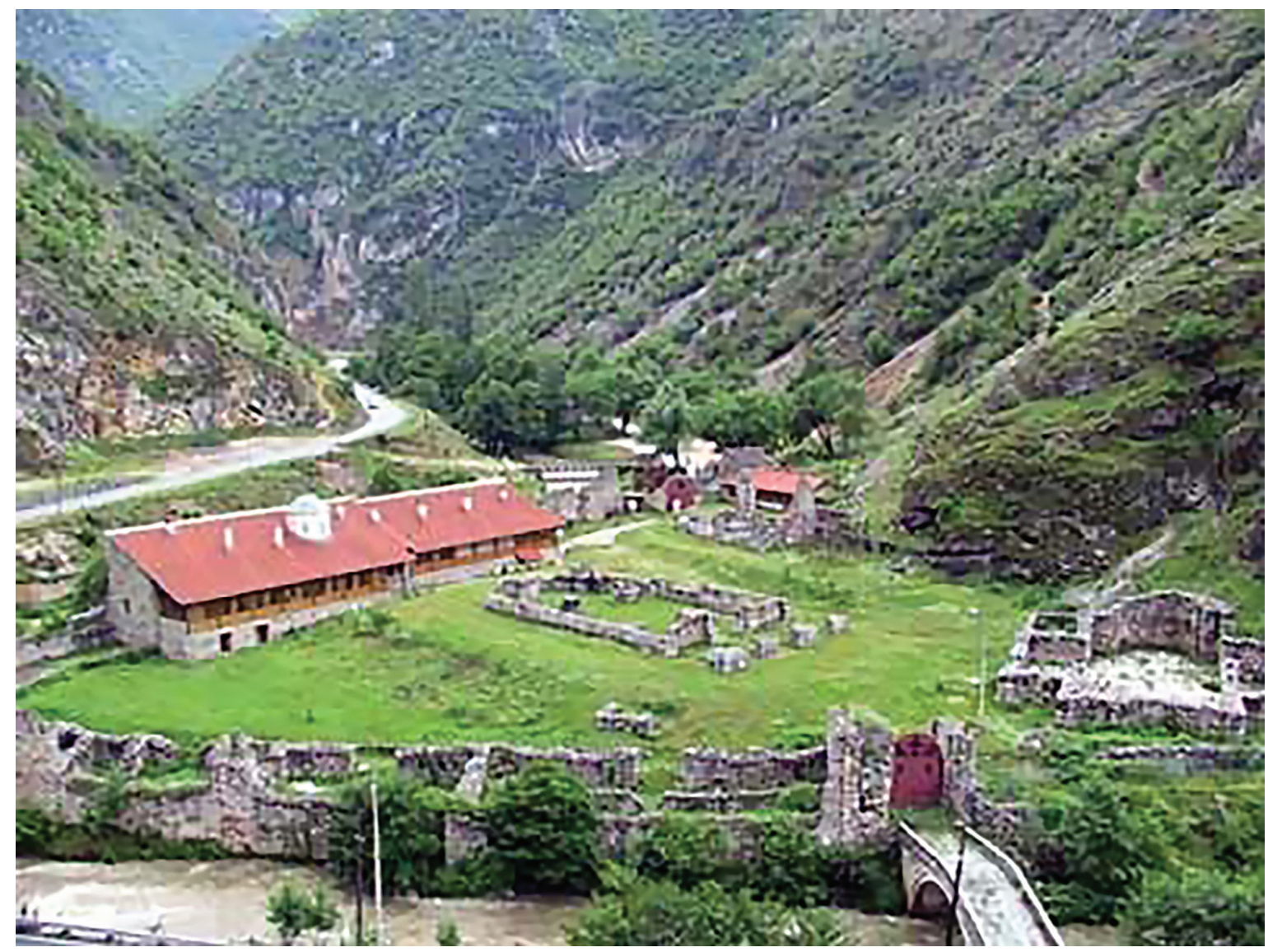

Слика 6. Манастир Св. Арханђели / Fig. 6. Monastery of The Holy Archangels

Након 2000. године културни пејзажи су препознати као битан фактор у успостављању равнотеже између очувања природног и културног наслеђа, као израза идентитета и диверзитета, и њихове употребе и као економски потенцијал, нарочито за развој туризма. Оперативне смернице за имплементацију Конвенције светске баштине (Unesko, 2016) указују да културни пејзажи представљају комбинацију природног и људског деловања и као такви илуструју еволуцију људског друштва и насеобина током времена (Unesko, 1999; Savet Evrope, 2000). Три су главне категорије културног пејзажа: у прву категорију спадају пејзажи које је човек циљано осмислио и направио и они се најлакше препознају, друга категорија обухвата органски настале пејзаже, који су резултат различитих потреба или захтева, социјалних, економских, административних и других и они остају у садашњем облику као последица спајања са њиховим окружењем или као одговор на њихово природно окружење, док трећа категорија укључује асоцијативне културне пејзаже, чија се вредност огледа више у снажној верској, уметничкој или културној повезаности природних елемената, него у материјалним културним доказима. (С. 6)

Поједини делови Косова и Метохије се, према својим карактеристикама, могу дефинисати као органски настали предели. Они су резултат симбиозе природних обележја региона (рударски басени, реке итд.) са људским творевинама, односно њиховим насеобинама, рудницима, домовима, утврђењима и манастирима насталим током средњег века, који су се даље развијали и након средњег века у различитим политичким и културним условима који су стварали нове вредности (базари, мостови, џамије итд.), као што је случај у Призрену, Пећи, Приштини и Ђаковици. Сходно томе, важно је дефинисати културне пејзаже средњовековних манастира и цркава на Косову и Метохији као развојне ресурсе и заштитити их, регулисати и искористити те пејзаже на начин који ће допринети успостављању регионалног и локалног идентитета у складу са савременим стандардима заштите. Да би се ово постигло, потребно је дефинисати оперативне циљеве српске и албанске стране, почевши од успостављања ефикасног законског и финансијског система, преко дефинисања стратегија и програма, инструмената и државне политике, као и наставка низа практичних задатака који се тичу одржавања стабилности, физичке и духовне структуре културних пејзажа, ограничавања интензитета њихове употребе и стопе развоја, заштите и очувања старих структура и стилова, са строгом контролом просторних промена и естетских стандарда и очувања постојећих просторних односа. Културни пејзаж би требало схватити као неопходан елемент људског окружења, као израз разноликости заједничког културног и природног наслеђа, као и темељ идентитета косовско-метохијског подручја. Од највеће је важности успоставити и применити политику пејзажа, која за циљ има заштиту, управљање и планирање датог пејзажа, усвајање процедура за укључивање опште јавности, локалних и регионалних власти и да интегрише 
тај пејзаж у политику просторног (регионалног) и урбаног развоја. Такође је кључно успоставити и организовати разне културне догађаје, друштвене односе у циљу успостављања мира и стабилности, као и економског и политичког развоја подручја Косова и Метохије.

До 2003. године на Листи светске културне и природне баштине су се налазила 32 културна пејзажа, од којих су неки били претходно уписани као појединачни културни споменици (Unesco, 2016). Један од њих је Урнешка дрвена црква (Church of Urnes, the stavkirke), која се налази у природном окружењу Согн ог Фјордане (Sogn og Fjordane), саграђена у 12. и 13. веку, као изузетан пример традиционалне скандинавске дрвене архитектуре. Угрожени локалитети светске баштине у Републици Сирији су културни пејзажи који укључују: древни град Алепо (Ancient City of Aleppo, 1986); древни град Босру (Ancien City of Bosra, 1980); древни град Дамаск (Ancien City of Damascus1979); древна села Северне Сирије (Ancien Villages of North Syeia, 2011); Крак де Шевалије и Саладинову цитаделу (Crac des Chevaliers i Qal'at Salah El-Din, 2006) и Предео Палмире (Site of Palmyra, 1980). Њихово сврставањеу категорију културних предела је допринело свеобухватном приступу у процени елемената неопходних за очување и одржавање ових културних локалитета. Наслеђе се схвата као јединство интегрисаног система међусобно повезаних делова. Стога, везе између делова имају већи значај него сами делови. Следећи наведене примере, Листа локалитета светске баштине на Косову и Метохији се може проширити и они се могу класификовати као културни пејзажи који интегришу неколико средњовековних манастира и насеобина са њиховом природном и друштвеном околином која се развила током историје и обухватила културно наслеђе различитих етничких група. То би обезбедило да сама заједница препозна њихов значај зарад очувања аутентичности и идентитета овог региона, али и за будући одрживи развој.

Поред тога, оквирна Конвенција Савета Европе о вредности културног наслеђа за друштво (The Council of Europe Faro Convention, 2005), коју је (рбија ратификовала, нуди подршку у циљу помоћи националним, регионалним или локалним властима и цивилном друштву у целини, зарад успостављања интегрисаног приступа у очувању културног наслеђа, као основног елемента будућег одрживог развоја. Идеја је да се промовише разумевање заједничког наслеђа Европе, које се састоји од свих облика културног наслеђа, а који заједно чине извор сећања, разумевања, идентитета, јединства, креативности и идеале, принципе и вредности добијене из искуства стеченог кроз напредак, као и некадашње сукобе, који подстичу развој мирног и стабилног друштва, утемељеног на принципима поштовања људских права, демократије и владавине закона. Конвенција наглашава: да свако, појединачно или колективно, има право на коришћење културног наслеђа и да допринесе његовом обогаћивању као и одговорност да поштује културну баштину других, колико и своју, а тиме и заједничку баштину Европе; да остваривање права на културну баштину може бити подложно само оним ограничењима која су неопходна у демократском друштву за заштиту јавног интереса, права и слобода других (Savet Evrope, 2005). Идеја одрживог развоја промовише значај очувања културно-историјског наслеђа и предела за будуће генерације, његову обнову, прихватање и интегрисање у савремени друштвени и економски развој, и третира наслеђе као саставни део развојног процеса који тежи трајном спречавању његовог уништавања и нестанка. На основу свега наведеног, више је него очигледно да Република Србија мора што пре уложити више напора да се укључе најновије међународне препоруке у методологију заштите баштине, које су усредсређене на заједницу и друштво, духовну и културну баштину, као и на значај њиховог очувања у контексту одрживог развоја Србије у будућности (Đukić et al., 2016).

\section{ЗАКЉУЧАК}

Поред наведене две међународне конвенције, очување и презентовање културног наслеђа на Косову и Метохији данас је неопходно повезати и са Конвенцијом за очување и заштиту нематеријалне културне баштине (Convention of the Safegarding of the Intangible (ultural Heritage) која нас подсећа на значај наслеђа као покретача културне различитости и гаранције одрживог развоја (Unesko, 2003). Аутентичност нематеријалног аспекта православног сакралног наслеђа Косова и Метохије, манастира и цркава, као и отоманског и албанског наслеђа, настала је кроз интерпретацију, физичке и дигиталне реконструкције у покушају да се евоцирају животи људи, њихове традиције и обреди. Културни предео Косова и Метохије осликава промене једне средњовековне сакралне области, касније постсредњовековне, а данас савремене урбане, индустријске и руралне области, која би могла постати савремена одржива област, као резултат еволуције друштва и његове нераскидиве везе са природом. С обзиром да културно и природно наслеђе представљају животно окружење људи, мора се спроводити комбинована акција за њихову заједничку заштиту, а у контексту међународног еколошког пристипа управљању простором. у складу са Европским конвенцијама и препорукама у области културног наслеђа, предео има значајну улогу у јавном интересу и областима културе, екологије, животне средине и на социјалном плану, а самим тим представља и важан потенцијал за привредну делатност, те сходно томе, заштита, управљање и планирање предела могу допринети отварању нових радних места, формирању и учвршћивању локалних култура, а тиме и учвршћивању европског идентитета чије су оне базичне компоненте (Evropska konvencija i preporuke, 2005:17-29).

Косово и Метохија није само подручје које испуњава критеријуме да презентује своје културно наслеђе као јединствено сведочанство о културној традицији и 0 
цивилизацији, већ кроз изузетне примере градитељског наслеђа и пејзажа оно је, такође, и симбол различитих култура и људске интеракције са околином. Будућим заштитарима овог предела остављено је да раде на унапређењу заштите овог јединственог пејзажа уз обавезу да га уз уважавање прошлости оставе будућим поколењима на коришћење и бригу. Један од најважнијих корака у овом процесу је унапређење свести локалне заједнице о значају наслеђа, и то путем размене знања и дијалога, а у складу са Повељом о међународном културном туризму, што би требало да буде подстрек да се локална заједница директно заинтересује за заштиту и очување, разумевање и уважавање заједничког наслеђа на овом простору (IKOMOS, 1999). Развијање културног туризма може допринети развоју и ревитализацији читавог региона, унапредити однос према културном наслеђу кроз настојања да се оно користи на уравнотежен и одржив начин, чиме би се такође утицало и на квалитет живота у локалним заједницама на Косову и Метохији (Evropske perspektive održivog razvoja, 2005:18-19).

Важан елемент у новом приступу очувању природног и културног наслеђа јесте укључивање различитих националних и регионалних културних и научних институција, невладиних организација и грађана у овај процес. Његов главни фокус усмерен је ка ланчаној сарадњи, што подразумева проактивне односе и напоре у циљу подстицања локалног становништва да оствари сарадњу са локалном самоуправом, свим актерима власти, као и интересним групама, грађанима итд. Активним учешћем свих наведених интересних група у процесе трансформације који утичу на њихову животну средину, стимулишу друштво, подржавају демократску културу и помажу свим јавним активностима да боље одговоре на потребе друштва, стварају се нови услови за „заједнички живот". У оваквом моделу развоја, наслеђе је предност, израз вредности, веровања, знања и традиција.

\section{ЛИТЕРАТУРА}

Bataković, D. (1998) Kosovo i Metohija: istorija i ideologija, Beograd, Hrišćanska misao Council of Europe (2000) European Landscape Convention, http://www.coe.int/en/ web/conventions/full-list/-/conventions/rms/0900001680080621

Council of Europe (2005) Framework Convention on the Value of Cultural Heritage for Society, Faro

Đukić, A., M. Roter Blagojević, M. Nikolić (2016) Serbian Cultural Territorial Systems First Experiences, in: F. Rotondo, F. Selicato, V. Marin and J. Lopez Galdeano (eds.) Cultural Territorial Systems - Landscape and Cultural Heritage as a Key to Sustainable and Local Development in Eastern Europe, Cham, Switzerland, Springer International Publishing, pp. 265-284.

Evropske konvencije i preporuke u oblasti kulturnog nasleđa (2005) EXPEDITIO - Centar za održivi prostorni razvoj, Herceg Novi

Zakon o kulturnim dobrima (The law on cultural properties) (1994), Official Gazette RS, 71/94.

ICOMOS (1999) International Cultural Tourism Charter - Managing Tourism at Places of Heritage Significance, www.icomos.org/charters/tourism_e.pdf

Kesić Ristić, S. et al. (2010) Svetska baština Srbija. Patrimoine Mondial Serbie, Beograd, Ministarstvo kulture Republike Srbije, Republički zavod za zaštitu spomenika kulture

Krstić, B. (2004) Kosovo facing the Court of History, New York, Humanity books

Marković, G. (2016) Zone zaštite srpskih manastira na Kosovu i Metohiji, doktorska disertacija (The zone of protection of Serbian monasteries in Kosovo and Metohija - PhD dissertation), Univerzitet u Beogradu - Arhitektonski fakultet
Milić, M., S. Pejić (1998) Spomeničko nasledje Srbije: nepokretna kulturna dobra od izuzetnog i velikog značaja (The monumental heritage of Serbia: immovable cultural property of extremely great importance), Beograd, Republički zavod za zaštitu spomenika kulture

Milić, M., S. Pejić (1999) Spomenička baština Kosova i Metohije, Beograd, Republički zavod za zaštitu spomenika kulture

Ministarstvo kulture RS (2016) Međunarodna dokumenta (International documents), http://www.kultura.gov.rs/lat/medjunarodna-saradnja/medjunarodnadokumenta

Nikolić, M., M. Vukotić Lazar, M. Roter Blagojević (2019) World cultural heritage in Kosovo and Metohija as a stability and peace factor in the region, in: Corinna Del Bianco (ed.) Proceedings of the International Symposium Heritage as a Builder of Peace, 1,2,3, March 2019, Part 2/2, Firenze, (Italy), Fondazione Romualdo Del Bianco Istituto Internazionale Life Beyond Tourism Edizioni, pp. 351-360.

Otašević, D. (ed.) (2017) Srpsko umetničko nasleđe na Kosovu i Metohiji - identitet, značaj, ugroženost (Serbian artistic heritage in Kosovo and Metohija - identity, significance, vulnerability), Beograd, Srpska akademija nauka i umetnosti

Pavlović, M., P. Marković (2006) Kosovo i Metohija: prošlost, pamćenje, stvarnost, Novi Sad, Preporod MM

PRIL, Prioritised Intervention List, Serbia (2008) European Commission - Council of Europe Joint Programme: Integrated Rehabilitation Project Plan / Survey of the Architectural and Archaeological Heritage (IRPP/SAAH), Belgrade, Ministry of Culture of the Republic of Serbia

Reljić, M. (2020) Srpska groblja na Kosovu i Metohiji uništena spomenička i jezička baština, Novi Sad, Matica srpska

Roter Blagojević, M., G. Milošević and A. Radivojević (2009) A New Approach to Renewal and Presentation of an Archaeological Site as Unique Cultural Landscape, Spatium 20, pp. 35-40.

Roter Blagojević, M., Vukotić-Lazar M., Nikolić M. (2016) Serbia: Current Risk in Heritage Protectin, in Heritage at Risc, World Report 2014-2015, on Monuments and Sites at Danger, edited by Christoph Machat and John Ziesemer, ICOMOS and Hendrik Bäßler verlag, Berlin, pp. 125-128.

RZZSK RS (2019) Republički zavod za zaštitu spomenika kulture republike Srbije - katalog nepokretnih kulturnih dobara (Republic Institute for Protection of Cultural Monuments of Serbia - catalog of immovable cultural property), http:// www.heritage.gov.rs/cirilica/nepokretna_kulturna_dobra.php, pristupljeno 10.02.2019.

UNESCO (1972) Convention concerning the Protection of the World Cultural and Natural Heritage, http://whc.unesco.org/archive/convention-en.pdf

UNESCO (2003) Convention for the Safeguarding of the Intangible Cultural Heritage, http://www.unesco.org/culture/ich/en/convention

UNESCO (2016a), List of World Heritage in Danger, https://whc.unesco.org/en/danger/ UNESCO (2016b), Cultural landscape's, https://whc.unesco.org/en/ list/?search=cultural+landscapes\&order=country

Curčić, S. (2010) Architecture on the Balkans, New Haven and London, Yale University Press

\section{ПОПИС И ПОРЕКЛО ИЛУСТРАЦИЈА}

Слика 1. Карта манастира и цркава на простору Косова и Метохије / Fig. 1. Мар of monasteries and churches in Kosovo and Metohija

(Извор: Објавила Скупштина града Београда, приређивач Београдске новине, 1998)

Слика 2. Споменици културе светске баштине на Косову и Метохији у опасности - Дечани, Пећка патријаршија, Грачаница и Богородица Љевишка / / Fig. 2. World Heritage Cultural Monuments in Kosovo and Metohija in Danger - Dečani, Pećka Patriarchate, Gračanica and Bogorodica Ljeviška

(Извор: слика горе лево) https://mitropolija.com/2020/11/12/medjunarodniput-decani-plav-zaobilazi-zasticenu-zonu-visokih-decana/?utm source=rss\&utm_medium=rss\&utm_campaign=medjunarodni-put-decaniplav-zaobilazi-zasticenu-zonu-visokih-decana; 10.10.2021.

(Извор: слика горе десно) https://turizamusrbiji.rs/manastir-peckapatrijarsija/; 10.10.2021.

(Извор: слика доле лево) https://turizamusrbiji.rs/manastir-peckapatrijarsija/; https://turizamusrbiji.rs/manastir-gracanica/; 10.10.2021.

(Извор: слика доле десно) https://visit-prizren.com/sr/rreth-prizrenit; 10.10.2021.

Слика 3. Уништавање цркава на простору Косова и Метохије / Fig. 3. Destruction of churches in Kosovo and Metohija

(Извор: http://tvk3.info/danas-17-godina-od-martovskog-pogroma-nadsrbima-na-kosovu-i-metohiji/; 10.10.2021)

Слика 4. Црква Богородице Љевишке у опасности / Fig. 4. Church of Bogorodica Ljeviška in danger

(Извор: https://mitropolija.com/2019/06/23/zapanjujuca-i-mracna-slika-kojusu-francuski-reporteri-videli-na-kosovu-i-metohiji/; 10.10.2021)

Слика 5. Манастир Бањска / Fig. 5. Banjska Monastery (Извор: httpsdodjiividi.blogspot.com201609blog-post_65.html; 10.10.2021.) Слика 6. Манастир Св. Арханђели / Fig. 6. Monastery of The Holy Archangels (Извор: http://www.kosovo.net/sarhangel.html; 10.10.2021) 